\title{
Effect of dietary fat supplementation on methane emissions from dairy cows fed wheat or corn
}

\author{
P. S. Alvarez-Hess, ${ }^{1,2 *}$ S. R. O. Williams, ${ }^{2}$ J. L. Jacobs,${ }^{2}$ M. C. Hannah, ${ }^{2}$ K. A. Beauchemin, ${ }^{3}$ R. J. Eckard, ${ }^{1}$ \\ W. J. Wales, ${ }^{2}$ G. L. Morris, ${ }^{2}$ and P. J. Moate ${ }^{2}$ \\ ${ }^{1}$ Faculty of Veterinary and Agricultural Science, The University of Melbourne, Parkville, Victoria 3010, Australia \\ ${ }^{2}$ Agriculture Research, Department of Economic Development, Jobs, Transport and Resources, Ellinbank, Victoria 3821, Australia \\ ${ }^{3}$ Agriculture and Agri-Food Canada, Lethbridge, Alberta, Canada T1J 4B1
}

\section{ABSTRACT}

Diets that contain high proportions of either wheat or supplementary fat have been individually reported to reduce enteric methane production. The objective of this research was to determine the effect of dietary fat supplementation on methane emissions and milk yield from cows fed diets containing either corn or wheat grains. It was hypothesized that cows fed a diet containing wheat would produce less methane and have lower methane yield (methane per $\mathrm{kg}$ of dry matter intake; MY) than cows fed a diet containing corn and that methane mitigation from fat supplementation would occur irrespective of the type of grain in the basal diet. The experiment involved 32 Holstein-Friesian dairy cows allocated to 1 of 4 treatment groups $(\mathrm{n}=8)$ and individually fed different diets restricted to approximately $90 \%$ of their mean ad libitum intake measured during a covariate period. All animals were offered $11.5 \mathrm{~kg}$ of dry matter/d of alfalfa hay, $1.8 \mathrm{~kg}$ of dry matter/d of solvent-extracted canola meal, and 1 of 4 dietary supplements. Dietary supplements were $8 \mathrm{~kg}$ of dry matter/d of either corn or wheat, or these same treatments with the addition of $0.8 \mathrm{~kg}$ of canola oil. In this 5-wk experiment, d 1 to 7 served as the covariate period, d 8 to 14 as the transition period, d 15 to 28 as the adaptation period, and d 29 to 35 as the experimental period. Cows were fed their full treatment diets from d 15 to 35 during which time milk production and feed intake were measured daily. During d 29 to 35, methane production was measured for individual cows daily using the sulfur hexafluoride tracer method. The resulting averages for milk production and feed intake were analyzed by analysis of covariance with factorial grain by fat as treatment structure, animal as the unit within blocks, and the corresponding milk production

Received March 8, 2018.

Accepted November 21, 2018.

*Corresponding author: pabloah@student.unimelb.edu.au or feed intake covariate averages as principal covariate. Data on milk fatty acids, ruminal fluid data on $\mathrm{pH}$, ammonia, volatile fatty acids, protozoa, and methane were analyzed by ANOVA using the same treatment and blocking structures excluding the principal covariate. Cows fed a diet containing wheat had greater MY than cows fed a diet containing corn. Irrespective of the type of grain in the diet, increasing the fat concentration from 2 to $6 \%$ dry matter reduced MY. It is concluded that the grain component in the basal diet does not affect the mitigating effects of dietary fat supplements on MY.

Key words: dairy, methane, dietary fat, wheat

\section{INTRODUCTION}

Methane is produced by ruminants through the fermentation of feedstuffs (Janssen, 2010; Lascano and Cárdenas, 2010). Approximately $6 \%$ of gross energy intake is lost to the dairy cow via eructation of ruminally produced methane (Appuhamy et al., 2016). Methane is a potent greenhouse gas and interest is growing in abating enteric methane production (Pacheco et al., 2014). One methane-mitigating strategy that has shown promising results is the addition of different methane mitigating agents to the diet of ruminants (Aluwong et al., 2011; Pacheco et al., 2014). It has been reported that diets containing high proportions of starch-rich grains such as wheat and corn produce less methane yield (MY) than forage-based diets (Beauchemin et al., 2008). Diets containing starch reduce enteric methane production by inhibiting the capacity of ruminal methanogens to take up hydrogen by reducing ruminal fluid $\mathrm{pH}$ and favoring the production of propionate over acetate (Van Kessel and Russell, 1996; Pirondini et al., 2015). The production of propionate in the rumen reduces MY because propiogenesis utilizes metabolic hydrogen that would otherwise be available to produce methane (Van Kessel and Russell, 1996; Pirondini et al., 2015). In this context, Williams et al. (2013) re- 
ported that substituting forage in the diet of dairy cows with $5 \mathrm{~kg} / \mathrm{d}$ of wheat grain reduced MY by up to $10 \%$ without affecting milk volume. Furthermore, Moate et al. (2014) reported decrease in MY of $31 \%$ when $50 \%$ of dietary forage fed to dairy cows was replaced with wheat grain. More recently, Moate et al. (2017) reported that dairy cows fed wheat grain instead of corn grain produced $33 \%$ less MY. This difference was attributed to the daily minimum ruminal $\mathrm{pH}$ that was correlated with MY (Moate et al., 2017).

Increasing the fat concentration of the diet has also been reported to reduce enteric methane production (Beauchemin et al., 2009; Moate et al., 2011). Dietary fat reduces methane production in the rumen by reducing hydrogen accumulation through fatty acid biohydrogenation, reducing the intake of fermentable OM, reducing fiber digestion, and by inhibiting the activity of ruminal methanogens (Grainger and Beauchemin, 2011; Bodas et al., 2012; Pirondini et al., 2015). McGinn et al. (2004) reported that MY was decreased by $17 \%$ when the diet of beef cattle was supplemented with sunflower oil at 5\% of dietary DM. Furthermore, Beauchemin and McGinn (2006) reported that MY was decreased by $15 \%$ when the diet of dairy and beef cattle was supplemented with canola oil at $4.6 \%$ of dietary DM. Similarly, Mata e Silva et al. (2017) reported that when the dietary fat concentration of dairy cows under grazing conditions was increased from 3 to $5 \%$ of dietary DM by inclusion of sunflower oil, daily methane production was reduced by $21 \%$ and MY by $20 \%$. However, Chung et al. (2011) found that daily methane emissions from cattle were reduced by $36 \%$ when a basal diet of barley silage was supplemented with a fat source (linseed), but no reduction occurred when the basal diet supplemented was pasture hay. Thus, it seems that the basal diet may influence the degree of methane mitigation resulting from dietary fat supplementation.

The objective of this research was to determine the effects of fat supplementation on methane emissions, MY (methane per $\mathrm{kg}$ of DMI), and milk yield from cows fed diets containing either corn or wheat grain. We hypothesized that (1) cows fed a diet containing wheat would produce less methane and have lower MY than cows fed a diet containing corn and that (2) methane mitigation from fat supplementation would occur irrespective of the type of grain in the basal diet.

\section{MATERIALS AND METHODS}

\section{Cows, Diets, and Management}

Thirty-two lactating, multiparous, rumen-cannulated Holstein-Friesian cows producing $24.9 \pm 4.07 \mathrm{~kg}$ of milk/d (mean \pm SD) at $5 \pm 2$ parities, at $207 \pm 13.6$ DIM, and with a BW of $635 \pm 43.3 \mathrm{~kg}$ were used in the experiment. Eight blocks of 4 cows were defined by milk yield and the 4 treatments were assigned to cows within each block, subject to balance for DIM, BW, and age using the COVDESIGN procedure in GenStat (Genstat 18th edition, VSN International Ltd., Hemel Hempstead, UK). All 4 dietary treatments consisted of a base of $11.5 \mathrm{~kg}$ of DM/d of chopped alfalfa hay, 1.8 $\mathrm{kg}$ of DM/d of solvent-extracted canola meal, $0.2 \mathrm{~kg}$ of $\mathrm{DM} / \mathrm{d}$ of minerals (calcium 10.5\%, magnesium $11.2 \%$, potassium $4.4 \%$, chloride $6.6 \%$, sulfur $14.2 \%$, and copper $34.4 \%$ ), and $42 \mathrm{~mL} / \mathrm{d}$ of Bloat-Drench (Victorian Chemical Company, Coolaroo, Victoria, Australia). In addition to this, the corn diet (CRN) included $8.0 \mathrm{~kg}$ of DM/d of crushed corn grain, the wheat diet (WHT) included $8.0 \mathrm{~kg}$ of $\mathrm{DM} / \mathrm{d}$ of crushed wheat grain, the corn plus fat diet (CPF) included $8.0 \mathrm{~kg}$ of $\mathrm{DM} / \mathrm{d}$ of crushed corn grain and $0.80 \mathrm{~kg} / \mathrm{d}$ of canola oil, and the wheat plus fat diet (WPF) included $8.0 \mathrm{~kg}$ of DM/d of crushed wheat grain and $0.80 \mathrm{~kg} / \mathrm{d}$ of canola oil. These feed amounts were chosen to supply approximately $90 \%$ of the mean ad libitum feed intake measured during a covariate period. This slight restriction in level of feed intake was chosen to allow comparison of MY at similar total DMI and to ensure that the cows in both treatment groups consumed diets with similar forage to concentrate ratios. This level of feed intake restriction and the separate feeding of concentrate and forage also reflect the feeding level and feeding practice that occur on many Australian commercial dairy farms. The corn and wheat grain had been passed once through a roller mill. For the corn grain, $62 \%$ had a particle size greater than $2 \mathrm{~mm}, 27 \%$ had a particle size between 1 and 2 $\mathrm{mm}$ and $10 \%$ had a particle size less than $1 \mathrm{~mm}$. For the wheat grain, $71 \%$ had a particle size greater than 2 $\mathrm{mm}, 21 \%$ had a particle size between 1 and $2 \mathrm{~mm}$, and $7 \%$ had a particle size less than $1 \mathrm{~mm}$.

All cows were offered a common diet in the lead up to the experiment, and in the covariate week (d 1 to 7 ) were offered daily $2.4 \mathrm{~kg}$ of DM of corn grain, $2.4 \mathrm{~kg}$ of DM of wheat grain, $1.2 \mathrm{~kg}$ of DM of cold pressed canola meal, $12 \mathrm{~kg}$ of DM of pasture, $5.5 \mathrm{~kg}$ of DM of pasture silage, and $250 \mathrm{~g}$ of DM of a mineral mix. On d 8 to 14 of the experiment, all cows were transitioned to their experimental diet. Days 15 to 28 served as an adaptation period. Methane measurements were undertaken on d 29 to 35 .

Cows were cared for according to the Australian Code of Practice for the Care and Use of Animals for Scientific Purposes (NHMRC, 2013). Animal use was approved by the Animal Ethics Committee of the Department of Economic Development, Jobs, Transport and Resources, Victoria, Australia. 
Table 1. Composition of main dietary ingredients ( $\mathrm{g} / \mathrm{kg}$ of DM, unless stated otherwise)

\begin{tabular}{|c|c|c|c|c|c|}
\hline Parameter $^{1}$ & Corn grain & Wheat grain & Canola meal & Canola oil & Alfalfa hay \\
\hline $\mathrm{ADF}$ & 39 & 37 & 231 & 0 & 389 \\
\hline $\mathrm{NDF}$ & 90 & 111 & 323 & 0 & 476 \\
\hline NFC & 735 & 718 & 166 & 0 & 210 \\
\hline Starch & 634 & 572 & 4.0 & 0 & 12 \\
\hline Crude fat & 53 & 22 & 20 & 1.000 & 24 \\
\hline
\end{tabular}

${ }^{1} \mathrm{GE}=$ gross energy.

\section{Feed and Milk}

Diets were offered to cows in 2 equal portions: one portion from 0700 to $1100 \mathrm{~h}$, and the other from 1600 to $2000 \mathrm{~h}$ each day. Cows were fed in individual feed stalls within a well-ventilated animal house (Williams et al., 2011) and were offered their concentrate including the grain, canola meal, mineral mix, bloat drench, and canola oil if needed, then alfalfa hay once all cows had finished their grain or 30 min had elapsed, whichever occurred first. Water was offered to all animals at least once during each feeding period. Quantities of concentrate offered to individual cows were weighed then mixed by hand before being offered. Refusals of concentrate were collected and removed after $30 \mathrm{~min}$ off offering and weighed, with proportions of each component being assumed to be the same as that offered on a wet basis. Refusals of alfalfa hay were also collected and weighed after each feeding. Dry matter intake was determined after each feeding. Grains offered were representatively sampled daily during the experiment. Alfalfa was representatively sampled at each feeding. Dry matter concentration was determined by drying feed samples in a forced draft oven at $105^{\circ} \mathrm{C}$ for $24 \mathrm{~h}$. Samples of each feed were kept frozen at $-18^{\circ} \mathrm{C}$, separately bulked over the duration of the experiment, then subsequently freeze-dried and ground to pass through a 1-mm screen (GEHL 95X Feed Grinder, West Bend, WI).

When not in the animal house, cows were either at the milking parlor being milked (0630 to $0700 \mathrm{~h}$ and 1500 to $1530 \mathrm{~h}$ ) or held in an open-air loafing-pad with no access to additional feed.

Milk yield was measured for each cow at each milking using a DeLaval Alpro milk metering system (MM25, DeLaval International, Tumba, Sweden). Milk samples were collected from individual cows during morning and afternoon milkings on d 5 to 7 (covariate period), 12 (transition period), 19 and 26 (adaptation period), and 31 to 35 (measurement period). Fat, protein, and lactose in these milk samples were measured by means of a near-infrared milk analyzer (model 2000, Bentley Instruments, Chaska, MN). Energy-corrected milk, standardized to $4.0 \%$ fat and $3.3 \%$ protein, was calculated using equation 1 (Tyrrell and Reid, 1965): ECM $(\mathrm{kg} /$ cow per $\mathrm{d})=[$ milk yield $(\mathrm{kg}) \times(376 \times$ fat $\%+209$ $\times$ protein $\%+948)] / 3,138$.

Feeds were analyzed by Dairy One Laboratories (Ithaca, NY) for CP (AOAC International 2000; method 990.03), DM (Goering and Van Soest, 1970), ADF (AOAC International 2000; method 7.074), NDF (AOAC International 2000; method 2002.04), lignin (AOAC International 2000; method 949.04), NFC (AOAC International 2000; method 992.09), starch (AOAC International 2000; method 996.11), crude fat (AOAC International 2000; method 2003.05), ash (AOAC International 2000; method 942.05), TDN (calculated), gross energy (calculated), and dietary cation-anion difference (calculated) by chemical analytical methods according to the published analytical procedures (Dairy One, 2015; Table 1).

\section{Methane Emissions}

The modified $\mathrm{SF}_{6}$ tracer technique as fully described by Deighton et al. (2014) was used to estimate methane emissions from individual cows. The permeation tubes were filled with about $2.8 \mathrm{~g}$ of $99.999 \%$ pure $\mathrm{SF}_{6}$ (Advanced Specialty Gases, Reno, NV). The release rate of $\mathrm{SF}_{6}$ from permeation tubes was determined by incubating the permeation tubes in an oven set at $39^{\circ} \mathrm{C}$ and weighing the permeation tubes twice per week for 4 wk. The $\mathrm{SF}_{6}$ release rate from permeation tubes was 5.4 $\pm 0.45 \mathrm{mg} / \mathrm{d}$ (average $\pm \mathrm{SD}$ ) and ranged from 4.4 to $6.4 \mathrm{mg} / \mathrm{d}$. Cows were dosed through the rumen cannula with $\mathrm{SF}_{6}$ permeation tubes on d 21. Each permeation tube was encapsulated in a clear gelatin capsule (size \#10 clear veterinary capsule, Torpac Inc., Fairfield, NJ). From d 29 to 35, evacuated canisters of 800-mL capacity were used to continuously sample eructated gases from a sampling point located just above the cows' 
nostrils. An initial sampling rate of $\sim 0.2 \mathrm{~mL} / \mathrm{min}$ was used to continuously sample eructated gases. Samples of background gases were collected from the right flank of each individual cow into evacuated $800-\mathrm{mL}$ canisters as per Williams et al. (2011). Canisters were exchanged once per day before the morning feeding at $\sim 0700 \mathrm{~h}$ for a total of $5 \mathrm{~d}$ of collection. Analysis of collected gas samples was carried out the day following collection using GC (Williams et al., 2011). A piston extractor (NIWA, Wellington, New Zealand) was used to extract a sample from the canister then deliver it to the GC (Moate et al., 2017). Four of the 310 gas samples were lost, 1 during analysis and 3 due to failure of the sampling equipment.

\section{Ruminal Fermentation}

Ruminal fluid samples $(\sim 400 \mathrm{~mL})$ were collected and combined from each cow from the reticulum, cranial sac, and ventral sac of the rumen per fistula, $4 \mathrm{~h}$ after feeding, on d 35, using a mesh-covered copper tube and a syringe (Boyne et al., 1957). Protozoa were counted in a $0.5-\mathrm{mL}$ representative sub-sample of ruminal fluid that had been transferred to a $12-\mathrm{mL}$ plastic vial and then diluted with $4.5 \mathrm{~mL}$ of a solution containing $4 \%$ formalin, $0.9 \%$ saline, and $0.4 \%$ methylene blue. Counting was done using a Mod-Fuchs-Rosenthal counting chamber and a Leica microscope (Leica Microsystems GmbH, Wetzlar, Germany). Protozoa were differentiated into epidinia (large) and entodiniomorphs (Punia and Leibholz, 1987).

Volatile fatty acid proportions were determined from a 4-mL sub-sample of ruminal fluid that had been centrifuged at $1,500 \times g$ and $4^{\circ} \mathrm{C}$ for $10 \mathrm{~min}$. Analysis for VFA was done according to the method of Packer et al. (2011).

Ammonia concentrations were determined from a 0.4-mL sub-sample from $50 \mathrm{~mL}$ of ruminal fluid that had been centrifuged at $1,500 \times g$ and $4^{\circ} \mathrm{C}$ for $10 \mathrm{~min}$ then diluted with $3.6 \mathrm{~mL}$ of $0.1 \mathrm{M} \mathrm{HCl}$. Ammonia concentrations in ruminal fluid were measured by the spectrophotometric method (AOAC International 2000; method 941.04).

The temperature and $\mathrm{pH}$ of ruminal fluid were continuously monitored by intra-ruminal boluses (KB5, Kahne Limited, Auckland, New Zealand) on d 28 to 35. In the week before insertion and the week after recovery, each bolus was sequenced in water baths set at 37 , 39 , and $41^{\circ} \mathrm{C}$ for at least $2 \mathrm{~h}$ in each bath to enable a temperature calibration. A pH calibration was done according to the manufacturer's instructions. Each bolus was fitted with a 750-g stainless-steel weight with the bolus administered per fistula into the rumen of each cow. The weight on each bolus ensured they resided at the bottom of the rumen. On d 35, the boluses were retrieved. Validation of $\mathrm{pH}$ was done in the week after removal. Linear interpolation was used to correct for any drift in $\mathrm{pH}$ and temperature as measured by individual boluses.

\section{Statistical Analyses}

Milk production data (milk yields, fat, protein and lactose concentrations and yields, ECM) and intakes (DMI) in the covariate period, and in the experimental period, were expressed as daily averages for each animal, before data analysis. The experiment was designed with 8 cows per treatment. However, one cow from the CRN treatment group was removed from the experiment due to health reasons unrelated to the treatment. Thus, there were 7 cows in the CRN treatment group and 8 cows in each of the other treatment groups. The resulting averages for milk production and feed intake were analyzed by analysis of covariance with factorial grain by fat as treatment structure, animal as the unit within blocks, and the corresponding milk production or feed intake covariate averages as principal covariate. Covariates for cow age, DIM, and BW were also included as a matter of course, as treatment groups were balanced for these in the design. Data on milk fatty acids, ruminal fluid data on $\mathrm{pH}$, ammonia, VFA, protozoa, and methane were analyzed by ANOVA using the same treatment and blocking structures excluding the principal covariate. The effects of fat within each grain were tested using contrasts between corresponding pairs of treatment of means in the analysis of covariance. Protozoa counts were log-transformed to better approximate normal distribution and constant variance assumptions of the ANOVA. All statistical analyses were performed using Genstat 18 software (VSN International Ltd.). Statistical difference between treatments was declared if $P<0.05$ and a trend when $P>$ 0.05 and $<0.1$.

\section{RESULTS}

A trend toward an interaction $(P=0.056)$ was observed between the effect of grain type and fat supplementation on milk yield, as well as an interaction $(P<$ $0.05)$ between grain type and fat supplementation for milk fat yield, protein yield, and lactose yield (Table 2 ). Milk fat yield was not different between cows fed the CRN and the CPF diets, and cows fed the WHT diet had greater $(P<0.05)$ milk fat yield than cows fed the WPF diet. Cows fed the CRN diet had less $(P$ $<0.05)$ protein and lactose yield than cows fed the 
Table 2. Feed intake and milk yields from cows on each treatment

\begin{tabular}{|c|c|c|c|c|c|c|c|c|}
\hline Parameter & $\mathrm{CRN}^{1}$ & WHT & $\mathrm{CPF}$ & WPF & $\mathrm{SED}^{2}$ & \multicolumn{3}{|c|}{ Contrast $P$-value } \\
\hline \multicolumn{9}{|c|}{ Feed intake $(\mathrm{kg}$ of $\mathrm{DM} / \mathrm{d})$} \\
\hline Corn grain & 7.51 & & 7.60 & & - & - & - & - \\
\hline Wheat grain & & 8.02 & & 7.9 & - & - & - & - \\
\hline Canola meal & 1.69 & 1.802 & 1.71 & 1.78 & - & - & - & - \\
\hline Total CP & 3.51 & 3.86 & 3.53 & 3.82 & - & - & - & - \\
\hline Total NDF & 6.59 & 6.88 & 6.60 & 6.79 & - & - & - & - \\
\hline Total starch & 4.90 & 4.73 & 4.96 & 4.67 & - & - & - & - \\
\hline Total fat & 0.70 & 0.49 & 1.46 & 1.27 & - & - & - & - \\
\hline Grain $^{3}(\%)$ & 36.1 & 37.4 & 35.5 & 36 & - & - & - & - \\
\hline $\mathrm{GEI}^{4}(\mathrm{MJ} / \mathrm{d})$ & 381 & 389 & 412 & 415 & - & - & - & - \\
\hline \multicolumn{9}{|c|}{ Milk composition $(\mathrm{g} / \mathrm{kg})$} \\
\hline Fat & 49.1 & 48.0 & 39.9 & 30.4 & 1.75 & $<0.001$ & $<0.001$ & 0.005 \\
\hline Protein & 34.1 & 34.0 & 32.9 & 31.8 & 1.18 & 0.413 & 0.045 & 0.563 \\
\hline Lactose & 49.7 & 49.4 & 50.4 & 47.8 & 0.87 & 0.025 & 0.492 & 0.102 \\
\hline
\end{tabular}

${ }^{1} \mathrm{CRN}=$ corn diet; $\mathrm{WHT}=$ wheat diet $\mathrm{CPF}=$ corn plus fat diet; $\mathrm{WPF}=$ wheat plus fat diet.

${ }^{2} \mathrm{SED}=$ standard error of difference.

${ }^{3}$ The percentage of either corn, barley, or wheat in each diet.

${ }^{4} \mathrm{GEI}=$ gross energy intake.

$\mathrm{CPF}$ diet, and no difference was observed between cows fed the WHT and the WPF diets. An interaction effect $(P=0.005)$ was observed between grain type and fat supplementation on ECM, as the addition of fat increased ECM in cows fed a diet that contained corn, but decreased ECM in cows fed a diet that contained wheat. An interaction effect $(P<0.01)$ was observed between grain type and fat supplementation on milk fat concentration. The decrease in milk fat concentration was more pronounced when cows fed diets that contained corn were supplemented with fat than when cows were fed diets that contained wheat. No difference was observed in milk protein or milk lactose concentration between treatments.

An interaction effect $(P=0.03)$ was observed between grain type and fat supplementation on mean methane emissions (g/d; Table 3). Dietary fat supplementation reduced $(P<0.05)$ daily methane production (637 vs. $569 \mathrm{~g} / \mathrm{d}$ ) in cows fed the WHT diet, but not in cows fed the CRN diet. Methane yields for diets containing corn were less $(P<0.01)$ than for diets containing wheat, and diets containing fat also had lower $(P<$ 0.01) MY than those fed diets not supplemented with fat. The effects of grain and fat supplementation on methane emissions expressed as a percentage of gross energy intake were similar to those for MY. Overall, cows fed diets containing corn had lower $(P=0.03)$ methane intensities (expressed as $\mathrm{g} / \mathrm{kg}$ of ECM) than cows fed diets containing wheat. Also, a tendency was observed for an interaction $(P=0.09)$ between the effects of grain type and fat supplementation on methane intensity.

Grain type and fat supplementation had no dietary effect on measured concentrations of $\mathrm{NH}_{3}-\mathrm{N}$ (Table 4). Cows fed diets containing corn had lower $(P<0.01)$ total ruminal VFA concentration than cows fed diets containing wheat, but dietary supplementation with fat had no effect on total VFA concentration. Cows fed diets containing corn had greater $(P<0.01)$ proportions of acetic acid than cows fed the diets containing wheat, and cows fed diets not supplemented with fat had a greater $(P=0.02)$ proportion of acetic acid than cows fed a diet supplemented with fat. Moreover, cows fed diets containing corn had a smaller $(P=0.01)$ proportion of propionic acid than that in the ruminal fluid of cows fed the diets containing wheat, and fat supplementation had no effect on propionic acid proportion. Cows fed diets containing corn had greater $(P<0.01)$ acetic acid to propionic acid ratio than cows fed diets containing wheat. Feeding diets containing corn resulted in greater $(P<0.05)$ proportions of iso-butyric acid and iso-valeric acid than feeding diets containing 
Table 3. Effects of diet on methane emissions, methane yield, and methane intensity between d 30 and 35 of the experiment

\begin{tabular}{|c|c|c|c|c|c|c|c|c|}
\hline Parameter & $\mathrm{CRN}^{1}$ & WHT & $\mathrm{CPF}$ & WPF & $\mathrm{SED}^{2}$ & \multicolumn{3}{|c|}{ Contrast $P$-value } \\
\hline $\mathrm{CH}_{4}(\mathrm{~g} / \mathrm{d})$ & 524 & 637 & 523 & 569 & 19.2 & $<0.001$ & 0.021 & 0.033 \\
\hline $\mathrm{CH}_{4}\left(\%\right.$ of $\left.\mathrm{GEI}^{3}\right)$ & 7.6 & 9.1 & 7.0 & 7.7 & 0.31 & $<0.001$ & $<0.001$ & 0.096 \\
\hline $\mathrm{CH}_{4}(\mathrm{~g} / \mathrm{kg}$ of ECM $)$ & 24.0 & 24.4 & 21.3 & 25.8 & 1.64 & 0.036 & 0.475 & 0.096 \\
\hline
\end{tabular}

${ }^{1} \mathrm{CRN}=$ corn diet; $\mathrm{WHT}=$ wheat diet; $\mathrm{CPF}=$ corn plus fat diet; WPF $=$ wheat plus fat diet.

${ }^{2} \mathrm{SED}=$ standard error of the difference.

${ }^{3} \mathrm{GEI}=$ gross energy intake.

wheat, and fat supplementation resulted in lower $(P<$ $0.01)$ proportions of iso-butyric acid and iso-valeric acid than not supplementing with fat. Feeding diets containing corn resulted in lower $(P<0.05)$ proportions of n-butyric and n-valeric acid compared with diets that contained wheat. Diets that included wheat resulted in greater counts of entodinia $(P=0.05)$ and total protozoa $(P=0.03)$ than diets that included corn. There was no effect of fat supplementation and no interaction between grain type and fat supplementation on counts of total protozoa. Grain type had no effect on mean $\mathrm{pH}$, minimum $\mathrm{pH}$, maximum $\mathrm{pH}$, or duration below $\mathrm{pH} 6$ as measured by intraruminal boluses during wk 5 of the experiment. Fat supplementation reduced mean $\mathrm{pH}(P$ $=0.02$ ) but had no effect on minimum $\mathrm{pH}$ or maximum $\mathrm{pH}$. Fat supplementation resulted in a trend $(P=0.07)$ for increased duration of $\mathrm{pH}$ below 6 .

\section{DISCUSSION}

Feeding cows a diet containing a high proportion of wheat grain resulted in greater MY than a diet containing a high proportion of corn, and grain type had no effect of on milk yield. Thus, we reject our first hypothesis that cows fed a diet containing a high proportion of wheat would produce less methane and have lower MY than cows fed a diet containing a high proportion of corn. In this context, our results differ from those reported in several previous studies (Moate et al., 2017, 2018b). In the study by Moate et al. (2017), cows fed wheat grain at $10 \mathrm{~kg}$ of $\mathrm{DM} / \mathrm{d}$ had a $30 \%$ lower MY than cows fed the equivalent amount of corn. It has been suggested that the relative ruminal degradability of starch has the potential to substantially influence methane emissions (Beauchemin et al., 2008; Moate et al., 2017). Starch

Table 4. Effect of diet on fermentation parameters in ruminal fluid samples collected $4 \mathrm{~h}$ postfeeding on d 35 of the experiment

\begin{tabular}{|c|c|c|c|c|c|c|c|c|}
\hline \multirow[b]{2}{*}{ Parameter } & \multirow[b]{2}{*}{$\mathrm{CRN}^{1}$} & \multirow[b]{2}{*}{ WHT } & \multirow[b]{2}{*}{$\mathrm{CPF}$} & \multirow[b]{2}{*}{ WPF } & \multirow[b]{2}{*}{$\mathrm{SED}^{2}$} & \multicolumn{3}{|c|}{ Contrast $P$-value } \\
\hline & & & & & & Grain & Fat & Grain $\times$ fat \\
\hline $\mathrm{NH}_{3}-\mathrm{N}(\mathrm{mg} / \mathrm{L})$ & 14.5 & 21.8 & 17.1 & 17.1 & 2.69 & 0.105 & 0.652 & 0.088 \\
\hline Total VFA $(\mathrm{m} M)$ & 97 & 128 & 104 & 129 & 8.4 & $<0.001$ & 0.518 & 0.621 \\
\hline \multicolumn{9}{|l|}{ Individual VFA (molar \%) } \\
\hline Acetic & 68.8 & 66.5 & 68.3 & 64.1 & 0.87 & $<0.001$ & 0.029 & 0.158 \\
\hline Propionic & 16.9 & 17.5 & 16.5 & 20.4 & 1.33 & 0.019 & 0.208 & 0.126 \\
\hline Iso-butyric & 1.5 & 1.2 & 1.2 & 0.9 & 0.08 & $<0.001$ & $<0.001$ & 0.791 \\
\hline n-Butyric & 9.8 & 11.4 & 11.0 & 11.6 & 0.67 & 0.035 & 0.113 & 0.327 \\
\hline Iso-valeric & 1.5 & 1.3 & 1.2 & 0.9 & 0.11 & 0.016 & $<0.001$ & 0.422 \\
\hline n-Valeric & 1.3 & 1.7 & 1.4 & 1.8 & 0.07 & $<0.001$ & 0.195 & 0.604 \\
\hline Caproic & 0.2 & 0.3 & 0.3 & 0.3 & 0.05 & 0.300 & 0.568 & 0.403 \\
\hline $\mathrm{A}: \mathrm{P}^{3}$ & 4.1 & 3.8 & 4.1 & 3.2 & 0.26 & 0.003 & 0.161 & 0.122 \\
\hline \multicolumn{9}{|l|}{ Protozoa $\left(10^{3}\right.$ cells $\left./ \mathrm{mL}\right)$} \\
\hline Entodinia & 182 & 489 & 244 & 335 & 72.5 & 0.050 & 0.856 & 0.136 \\
\hline Epidinia & 15 & 28 & 19 & 22 & 12.6 & 0.187 & 0.242 & 0.483 \\
\hline Total protozoa & 188 & 525 & 268 & 363 & 75.8 & 0.035 & 0.856 & 0.102 \\
\hline Mean $\mathrm{pH}^{4}$ & 6.63 & 6.76 & 6.53 & 6.43 & 0.13 & 0.763 & 0.028 & 0.256 \\
\hline Minimum $\mathrm{pH}^{4}$ & 6.01 & 6.29 & 6.0 & 5.94 & 0.18 & 0.656 & 0.187 & 0.245 \\
\hline Maximum $\mathrm{pH}^{4}$ & 7.11 & 7.23 & 7.08 & 7.01 & 0.11 & 0.915 & 0.141 & 0.295 \\
\hline Duration below $\mathrm{pH} 6^{4}(\min )$ & 61.8 & 16.9 & 146.1 & 163.4 & 104.3 & 0.921 & 0.074 & 0.562 \\
\hline
\end{tabular}

${ }^{1} \mathrm{CRN}=$ corn diet; WHT $=$ wheat diet; $\mathrm{CPF}=$ corn plus fat; WPF $=$ wheat plus fat.

${ }^{2} \mathrm{SED}=$ standard error of the difference.

${ }^{3}$ Acetic acid to propionic acid ratio.

${ }^{4}$ Ruminal fluid $\mathrm{pH}$ parameters continuously measured by means of an intra-ruminal bolus over the last $5 \mathrm{~d}$ of the experiment. 
in wheat grain is known to be more quickly fermented in the rumen than starch in corn grain; thus, it was expected that cows fed the diet containing wheat would produce less methane than cows fed the diet containing corn (Herrera-Saldana et al., 1990; McAllister et al., 1990). Furthermore, cows fed diets that contained corn had greater acetic acid to propionic acid ratio than cows fed diets that contained wheat, which has previously been associated with greater MY (Moss et al., 2000). In this context, our results are different from the findings reported in previous studies. A series of factors could explain the apparently anomalous finding of lower methane production and MY from the cows fed the diet containing corn. First, cows fed the diet containing corn had lower NDF intake than cows fed the diet containing wheat. It has previously been reported that NDF affects methane production in the rumen and that increasing NDF concentration in the diet leads to increased methane production (Ellis et al., 2007). This was observed in a study by Beauchemin and McGinn (2005) in which steers were fed diets based either on barley grain or corn grain, and it was reported that the cattle fed the barley-based diets had greater NDF intake and produced more methane than the cattle fed the corn-based diet. In the study by Moate et al. (2017), the NDF intake of the wheat-fed cows was $5.85 \mathrm{~kg}$ of $\mathrm{DM} / \mathrm{d}$ and was slightly lower than that of the corn-fed cows $(5.97 \mathrm{~kg}$ of $\mathrm{DM} / \mathrm{d})$. Second, in our study the cows fed the diets containing corn had a greater fat intake than cows fed the diets containing wheat and it has been reported that an increased fat intake is associated with lower methane production (Moate et al., 2011).

Although cows fed the diet containing corn consumed a diet that had a lower dietary NDF concentration and greater fat concentration than the wheat diet, the equations of Ellis et al. (2007) and Moate et al. (2011) indicate that differences in the concentrations of these components were insufficient to explain the different MY. Furthermore, the crude fat component of corn is partially composed of wax and pigments, which are inactive and not fermented in the rumen (Moate et al., 2004) and therefore would not explain the different MY between animals fed wheat and corn grain.

Moate et al. (2017) reported that ruminal fluid $\mathrm{pH}$ from cows fed a diet containing a high proportion of wheat had a greater duration of $\mathrm{pH}$ below 6 , which was inversely correlated with methane production. Moate et al. (2017) also reported that ruminal fluid from wheatfed cows contained fewer entodinia, epidinia, and total protozoa than that of cows fed the corn diet. However, a similar reduction in ruminal fluid $\mathrm{pH}$ and protozoal population was not observed in the present study. Ruminal fluid from cows fed the diet containing wheat contained greater total protozoa counts than cows fed the containing corn. It has been reported that methane production is associated with protozoa population, as methanogens residing on the exterior surface of the ruminal ciliate protozoa are estimated to produce up to $37 \%$ of the methane in the rumen (Hegarty, 1999; Brossard et al., 2004). It has also been reported that a decrease in ruminal $\mathrm{pH}$ is associated with a reduction in the ruminal protozoa population (Hegarty, 1999; Brossard et al., 2004). Normally, the quick fermentation of starch in diets containing wheat would be associated with an accumulation of lactic acid in ruminal fluid and an associated reduction in ruminal fluid $\mathrm{pH}$ and reduction in protozoal count, which would favor production of propionate, thereby reducing methane production (Dijkstra et al., 2012; Moate et al., 2017). In contrast, in this experiment, the reduction in ruminal fluid $\mathrm{pH}$ and protozoa population reported in other studies when cows were fed diets that contained wheat, was not observed. Furthermore, the concentrations of D and $\mathrm{L}$ lactate in ruminal fluid were relatively low and would not have had any biological significance with respect to effects on ruminal protozoa or methanogenesis (Van Kessel and Russell, 1996). This is consistent with the lack of the expected inhibitory effect on methane related parameters.

A factor affecting methane response is the adaptation of ruminal microorganisms to the diet (Klop et al., 2017). In a recent study by Moate et al. (2018a), it was found that when feeding wheat and corn over a 16 -wk period, at wk 4, cows fed the diet containing wheat produced $42 \%$ less methane than cows fed the diet containing corn. However, by wk 16 the diets were not different in terms of methane emissions and MY. In the current experiment, cows had been fed a high-grain diet for $12 \mathrm{wk}$ before treatment allocation and a further 4 wk before methane was measured. We propose that in our study, adaptation of ruminal microorganisms to a high-grain diet may have limited the inhibitory effect of wheat on ruminal fermentation parameters and methane response.

Increasing the fat concentration of the diet reduced daily mean methane emissions in cows fed the diet containing wheat but not in cows fed the diet containing corn. However, daily mean methane emissions are primarily determined by DMI, which determines the level of substrate available for fermentation in the rumen (Johnson and Johnson, 1995; Oss et al., 2016). For $\mathrm{MY}$ and $\mathrm{CH}_{4}$ as a percentage of gross energy intake, there was no interaction between the effect of type of grain and fat supplementation. Thus, we accept our second hypothesis that methane mitigation from fat supplementation would occur irrespective of the type of grain in the basal diet. It has been reported that MY is reduced by $3.5 \%$ with each increase of $10 \mathrm{~g} / \mathrm{kg}$ of DM 
in dietary fat concentration (Moate et al., 2011). In our experiment, compared with the WHT and CRN diets, the WPF and CPF diets contained an extra $40 \mathrm{~g}$ of fat per $\mathrm{kg}$ of $\mathrm{DM}$, and this resulted in a $10 \%$ reduction in MY on average, a value similar to the $14 \%$ expected by the estimation of Moate et al. (2011). Evidence in the scientific literature indicates that the basal diet can influence the magnitude of the methane inhibitory effect from a fat supplement. For example, Chung et al. (2011) reported that when Holstein cows were fed a diet based on whole-crop barley silage supplemented with $150 \mathrm{~g} / \mathrm{kg}$ of DM of a high-fat linseed, MY was reduced by $33 \%$, but there was no effect on MY when a high-fat linseed supplement was fed with a diet based on chopped grass hay. Similar results have been reported from an experiment by Bayat et al. (2017), where sunflower oil fed at a rate of $50 \mathrm{~g} / \mathrm{kg}$ DM to Nordic red dairy cows was more effective in reducing MY when concentrate constituted a low (35\% of DM) proportion of the basal diet than when concentrate constituted a high $(65 \%$ of DM) proportion. Our results indicate that the type of grain in the basal diet of dairy cows does not affect the methane mitigating effect of dietary fat.

Increasing the fat concentration of the diet did not reduce DMI. However, in this experiment all cows were offered $90 \%$ of their ad libitum intake, and it is possible that fat supplementation may not have been effective in reducing DMI in these circumstances. Furthermore, it has been reported that if dietary fat concentration remains below $7 \%$ of daily DMI, there is no effect on DMI (Beauchemin et al., 2008). In this context, our findings are consistent with those of previous studies on the feeding of fats to ruminants (Gonthier et al., 2005; Loor et al., 2005; Bu et al., 2007). For cows fed diets containing wheat, increasing the fat concentration of the diet reduced ECM, driven by a decrease in milk fat concentration. The decrease in milk fat concentration was likely caused by reduced digestibility of fiber in the rumen as a consequence of a high level of fat intake and also by reduced mammary lipogenesis caused by adding polyunsaturated fats to a starch-rich diet (Martin et al., 2008; Chilliard et al., 2009). Similar results have been reported by Martin et al. (2008), where a diet containing linseed oil at a rate of $5.7 \%$ of DMI reduced milk fat concentration by $8.8 \mathrm{~g} / \mathrm{kg}$. In addition, increasing the fat concentration decreased mean ruminal $\mathrm{pH}$ measured during the last $5 \mathrm{~d}$ of the experiment and measured on the last day of the experiment at 4 $\mathrm{h}$ postfeeding. Increasing fat content in the diet also increased the duration of $\mathrm{pH}$ below 6 . This finding is in agreement with the study of McGinn et al. (2004) where the supplementation of sunflower oil in the diet of beef cattle fed a high-forage diet decreased ruminal $\mathrm{pH}$ from 7.04 to 6.75 . This could also explain the effect of fat supplementation on MY, as it has been reported that decreased ruminal fluid $\mathrm{pH}$ is associated with lower methane emissions (Van Kessel and Russell, 1996).

Across all diets, daily methane production and MY were within the range of values commonly reported in the scientific literature (Niu et al., 2018). However, in our study, cows produced more methane than cows in previous similar studies involving feeding wheat- or corn-based diets (Charmley et al., 2016; Moate et al., 2017). We propose that this difference may be associated with the high fiber concentration of the alfalfa hay fed to the cows in our experiments. In our study, cows fed CRN and WHT diets had a NDF intake of 6.59 and $6.88 \mathrm{~kg}$ of $\mathrm{DM} / \mathrm{d}$, respectively, whereas in the study by Moate et al. (2017), the cows fed similar corn- and wheat-based diets had a NDF intake of 5.97 and 5.85 $\mathrm{kg}$ of $\mathrm{DM} / \mathrm{d}$, respectively. Diets with more NDF content are associated with increased methane production, because acetate is a major end product of the fermentation of NDF and acetate enhances methane formation (Johnson and Johnson, 1995). Some authors suggest that high MY can be related to stage of lactation, with MY increasing toward late lactation (Grainger et al., 2010; Alstrup et al., 2015). Higher MY may be associated with slower passage rate in late lactation, which leads to increase residence time of feeds in the rumen and increased degradation, especially of the slowly degradable fiber fraction. The net effect would be increased methane production (Alstrup et al., 2015). In this context, studies by Moate et al. (2017) and Bayat et al. (2017), which reported lower MY than those observed in this study, used cows in peak lactation (71 and 89 DIM, respectively) compared with our study that used cows in late lactation (207 DIM).

\section{CONCLUSIONS}

Under these experimental conditions with feed intake restricted to approximately $90 \%$ of ad libitum DMI, increasing the fat concentration of the diet reduced MY ( $\mathrm{g} / \mathrm{kg}$ of DMI) irrespective of the type of grain in the diet. Furthermore, ECM was increased in cows fed the corn-based diet and decreased in cows fed the wheatbased diet. It is concluded that the grain component in the basal diet does not affect the mitigating effects of dietary fat supplements on MY.

\section{ACKNOWLEDGMENTS}

This investigation was funded by the Victorian Department of Economic Development, Jobs, Transport and Resources; Emissions Reduction, Alberta, Canada; and Dairy Australia. This work would not have been possible without the excellent support of the technical 
staff at Department of Economic Development, Jobs, Transport and Resources (Victoria, Ellinbank Centre, Australia).

\section{REFERENCES}

Alstrup, L., A. L. F. Hellwing, P. Lund, and M. R. Weisbjerg. 2015. Effect of fat supplementation and stage of lactation on methane production in dairy cows. Anim. Feed Sci. Technol. 207:10-19. https://doi.org/10.1016/j.anifeedsci.2015.05.017.

Aluwong, T., P. A. Wuyep, and L. Allam. 2011. Livestock-environment interactions: Methane emissions from ruminants. Afr. J. Biotechnol. 10:1265-1269. https://doi.org/10.5897/AJB10.1117.

AOAC International. 2000. Official Methods of Analysis. 17th ed. AOAC International, Arlington, VA.

Appuhamy, J. A., J. France, and E. Kebreab. 2016. Models for predicting enteric methane emissions from dairy cows in North America, Europe, and Australia and New Zealand. Glob. Change Biol. 22:3039-3056. https://doi.org/10.1111/gcb.13339.

Bayat, A. R., L. Ventto, P. Kairenius, T. Stefański, H. Leskinen, I. Tapio, E. Negussie, J. Vilkki, and K. J. Shingfieldeld. 2017. Dietary forage to concentrate ratio and sunflower oil supplement alter rumen fermentation, ruminal methane emissions, and nutrient utilization in lactating cows. Transl. Anim. Sci. 1:277-286. https:/ /doi.org/10.2527/tas2017.0032.

Beauchemin, K. A., M. Kreuzer, F. O'Mara, and T. A. McAllister. 2008. Nutritional management for enteric methane abatement: A review. Aust. J. Exp. Agric. 48:21-27. https://doi.org/10.1071/ EA07199.

Beauchemin, K. A., T. A. McAlister, and S. M. McGinn. 2009. Dietary mitigation of enteric methane from cattle. Perspect. Agric. Vet. Sci. Nutr. Nat. Resour. 4:35. https://doi.org/10.1079/ PAVSNNR20094035.

Beauchemin, K. A., and S. M. McGinn. 2005. Methane emissions from feedlot cattle fed barley or corn diets. J. Anim. Sci. 83:653-661. https://doi.org/10.2527/2005.833653x.

Beauchemin, K. A., and S. M. McGinn. 2006. Methane emissions from beef cattle: Effects of fumaric acid, essential oil, and canola oil. J. Anim. Sci. 84:1489-1496. https://doi.org/10.2527/2006.8461489x.

Bodas, R., N. Prieto, R. García-González, S. Andrés, F. J. Giráldez, and S. López. 2012. Manipulation of rumen fermentation and methane production with plant secondary metabolites. Anim. Feed Sci. Technol. 176:78-93. https://doi.org/10.1016/j.anifeedsci.2012 .07 .010 .

Boyne, A. W., J. M. Eadie, and K. Raitt. 1957. The development and testing of a method of counting rumen ciliate protozoa. J Gen. Microbiol. 17:414-423. https://doi.org/10.1099/00221287-17 $-2-414$.

Brossard, L., C. Martin, F. Chaucheyras-Durand, and B. MichaletDoreau. 2004. Protozoa involved in butyric rather than lactic fermentative pattern during latent acidosis in sheep. Reprod. Nutr. Dev. 44:195-206. https://doi.org/10.1051/rnd:2004023.

Bu, D. P., J. Q. Wang, T. R. Dhiman, and S. J. Liu. 2007. Effectiveness of oils rich in linoleic and linolenic acids to enhance conjugated linoleic acid in milk from dairy cows. J. Dairy Sci. 90:998-1007. https://doi.org/10.3168/jds.S0022-0302(07)71585-0.

Charmley, E., S. R. O. Williams, P. J. Moate, R. S. Hegarty, R. M. Herd, V. H. Oddy, P. Reyenga, K. M. Staunton, A. Anderson, and M. C. Hannah. 2016. A universal equation to predict methane production of forage-fed cattle in Australia. Anim. Prod. Sci. 56:169-180. https://doi.org/10.1071/AN15365.

Chilliard, Y., C. Martin, J. Rouel, and M. Doreau. 2009. Milk fatty acids in dairy cows fed whole crude linseed, extruded linseed, or linseed oil, and their relationship with methane output. J. Dairy Sci. 92:5199-5211. https://doi.org/10.3168/jds.2009-2375.

Chung, Y. H., M. L. He, S. M. McGinn, T. A. McAllister, and K. A. Beauchemin. 2011. Linseed suppresses enteric methane emissions from cattle fed barley silage, but not from those fed grass hay. Anim. Feed Sci. Technol. 166:321-329. https://doi.org/10.1016/j .anifeedsci.2011.04.022.
Dairy One. 2015. Analytical procedures. Accessed May 15, 2018. http://dairyone.com/wp-content/uploads/2014/02/Forage-Lab -Analytical-Procedures-Listing-Alphabetical-July-2015.pdf.

Deighton, M. H., S. R. O. Williams, M. C. Hannah, R. J. Eckard, T. M. Boland, and P. J. Moate. 2014. A modified sulphur hexafluoride tracer technique enables accurate determination of enteric methane emissions from ruminants. Anim. Feed Sci. Technol. 197:47-63. https://doi.org/10.1016/j.anifeedsci.2014.08.003.

Dijkstra, J., J. L. Ellis, E. Kebreab, A. B. Strathe, S. López, J. France, and A. Bannink. 2012. Ruminal pH regulation and nutritional consequences of low pH. Anim. Feed Sci. Technol. 172:22-33. https:// doi.org/10.1016/j.anifeedsci.2011.12.005.

Ellis, J. L., K. Kebreab, N. E. Odongo, B. W. McBride, E. K. Okine, and J. France. 2007. Prediction of methane production from dairy and beef cattle. J. Dairy Sci. 90:3456-3466. https://doi.org/10 $.3168 /$ jds.2006-675.

Goering, H. K., and P. J. Van Soest. 1970. Forage Fiber Analysis. USDA Agricultural Research Service. Handbook number 379. US Department of Agriculture. Superintendent of Documents, US Government Printing Office, Washington, DC.

Gonthier, C., A. F. Mustafa, D. R. Ouellet, P. Y. Chouinard, R. Berthiaume, and H. V. Petit. 2005. Feeding micronized and extruded flaxseed to dairy cows: Effects on blood parameters and milk fatty acid composition. J. Dairy Sci. 88:748-756. https://doi.org/10 .3168/jds.S0022-0302(05)72738-7.

Grainger, C., and K. A. Beauchemin. 2011. Can enteric methane emissions from ruminants be lowered without lowering their production? Anim. Feed Sci. Technol. 166:308-320. https://doi.org/10 .1016/j.anifeedsci.2011.04.021.

Grainger, C., R. Williams, T. Clarke, A. D. Wright, and R. J. Eckard. 2010. Supplementation with whole cottonseed causes long-term reduction of methane emissions from lactating dairy cows offered a forage and cereal grain diet. J. Dairy Sci. 93:2612-2619. https:// doi.org/10.3168/jds.2009-2888.

Hegarty, R. S. 1999. Reducing rumen methane emissions through elimination of rumen protozoa. Aust. J. Agric. Res. 50:1321-1328. https://doi.org/10.1071/AR99008.

Herrera-Saldana, R. E., J. T. Huber, and M. H. Poore. 1990. Dry matter, crude protein, and starch degradability of five cereal grains. J. Dairy Sci. 73:2386-2393. https://doi.org/10.3168/jds.S0022 -0302(90)78922-9.

Janssen, P. H. 2010. Influence of hydrogen on rumen methane formation and fermentation balances through microbial growth kinetics and fermentation thermodynamics. Anim. Feed Sci. Technol. 160:1-22. https://doi.org/10.1016/j.anifeedsci.2010.07.002.

Johnson, K. A., and D. E. Johnson. 1995. Methane emissions from cattle. J. Anim. Sci. 73:2483-2492. https://doi.org/10.2527/1995 $.7382483 \mathrm{x}$

Klop, G., J. Dijkstra, K. Dieho, W. H. Hendricks, and A. Bannink. 2017. Enteric methane production in lactating dairy cows with continuous feeding of essential oils or rotational feeding of essential oils and lauric acid. J. Dairy Sci. 100:3563-3575. https://doi.org/ 10.3168/jds.2016-12033.

Lascano, C. E., and E. Cárdenas. 2010. Alternatives for methane emission mitigation in livestock systems. Rev. Bras. Zootec. 39:175182. https://doi.org/10.1590/S1516-35982010001300020.

Loor, J. J., A. Ferlay, A. Ollier, M. Doreau, and Y. Chilliard. 2005. Relationship among trans and conjugated fatty acids and bovine milk fat yield due to dietary concentrate and linseed oil. J. Dairy Sci. 88:726-740. https://doi.org/10.3168/jds.S0022-0302(05)72736-3.

Martin, C., J. Rouel, J. P. Jouany, M. Doreau, and Y. Chilliard. 2008. Methane output and diet digestibility in response to feeding dairy cows crude linseed, extruded linseed, or linseed oil. J. Anim. Sci. 86:2642-2650. https://doi.org/10.2527/jas.2007-0774.

Mata e Silva, B. M., F. C. F. Lopes, L. G. R. Pereira, T. R. Tomich, M. J. F. Morenz, C. E. Martins, C. A. M. Gomide, D. S. C. Paciullo, R. M. Maurício, and A. V. Chaves. 2017. Effect of sunflower oil supplementation on methane emissions of dairy cows grazing Urochloa brizantha cv. marandu. Anim. Prod. Sci. 57:1431-1436. https://doi.org/10.1071/AN16470. 
McAllister, T. A., L. M. Rode, D. J. Major, K. J. Cheng, and J. G. Buchanan-Smith. 1990. Effect of ruminal microbial colonization on cereal grain digestion. Can. J. Anim. Sci. 70:571-579. https://doi .org/10.4141/cjas90-069.

McGinn, S. M., K. A. Beauchemin, T. Coates, and D. Colombatto. 2004. Methane emissions from beef cattle: Effects of monensin, sunflower oil, enzymes, yeast, and fumaric acid. J. Anim. Sci. 82:3346-3356. https://doi.org/10.2527/2004.82113346x.

Moate, P. J., W. Chalupa, T. C. Jenkins, and R. C. Boston. 2004. A model to describe ruminal metabolism and intestinal absorption of long chain fatty acids. Anim. Feed Sci. Technol. 112:79-105. https: //doi.org/10.1016/j.anifeedsci.2003.10.007.

Moate, P. J., J. L. Jacobs, M. C. Hannah, G. L. Morris, K. A. Beauchemin, P. S. Alvarez Hess, R. J. Eckard, Z. Liu, S. Rochfort, W. J. Wales, and S. R. O. Williams. 2018a. Adaptation responses in milk fat yield and methane emissions of dairy cows when wheat was included in their diet for 16 weeks. J. Dairy Sci. https://doi.org/ 10.3168 /jds.2017-14334.

Moate, P. J., S. R. O. Williams, M. H. Deighton, M. C. Hannah, B. E. Ribaux, G. L. Morris, J. L. Jacobs, J. Hill, and W. J. Wales. 2018b. Effects of feeding wheat or corn and of rumen fistulation on milk production and methane emissions of dairy cows. Anim. Prod. Sci. https://doi.org/10.1071/AN17433.

Moate, P. J., S. R. O. Williams, M. H. Deighton, W. J. Wales, and J. L. Jacobs. 2014. Supplementary feeding of wheat to cows fed harvested pasture increases milk production and reduces methane yield. Pages 176-178 in Proc. 6th Australasian Dairy Science Symposium, Hamilton, New Zealand. The Australasian Dairy Science Symposium Committee, Hamilton, New Zealand.

Moate, P. J., S. R. O. Williams, C. Grainger, M. C. Hannah, E. N. Ponnampalam, and R. J. Eckard. 2011. Influence of cold-pressed canola, brewers grains and hominy meal as dietary supplements suitable for reducing enteric methane emissions from lactating dairy cows. Anim. Feed Sci. Technol. 166:254-264. https://doi .org/10.1016/j.anifeedsci.2011.04.069.

Moate, P. J., S. R. O. Williams, J. L. Jacobs, M. C. Hannah, K. A. Beauchemin, R. J. Eckard, and W. J. Wales. 2017. Wheat is more potent than corn or barley for dietary mitigation of enteric methane emissions from dairy cows. J. Dairy Sci. 100:7139-7153. https: //doi.org/10.3168/jds.2016-12482.

Moss, A. R., J. P. Jouany, and J. Newbold. 2000. Methane production by ruminants: Its contribution to global warming. Ann. Zootech. 49:231-253. https://doi.org/10.1051/animres:2000119.

NHMRC. 2013. Australian Code of Practice for the Care and Use of Animals for Scientific Purposes. 7th ed. Accessed Nov. 22, 2017. https://nhmrc.gov.au/about-us/publications/australian-code-care -and-use-animals-scientific-purposes.
Niu, M., E. Kebreab, A. N. Hristov, J. Oh, C. Arndt, A. Bannink, A. R. Bayat, A. F. Brito, T. Boland, and D. Casper. 2018. Prediction of enteric methane production, yield, and intensity in dairy cattle using an intercontinental database. Glob. Change Biol. 24:3368 3389. https://doi.org/10.1111/gcb.14094.

Oss, D. B., M. I. Marcondes, F. S. Machado, L. G. R. Pereira, T. R. Tomich, G. O. Ribeiro Jr., M. L. Chizzotti, A. L. Ferreira, M. M. Campos, R. M. Mauricio, A. V. Chaves, and T. A. McAllister. 2016. An evaluation of the face mask system based on short-term measurements compared with the sulfur hexafluoride $\left(\mathrm{SF}_{6}\right)$ tracer and respiration chamber techniques for measuring $\mathrm{CH}_{4}$ emissions. Anim. Feed Sci. Technol. 216:49-57. https://doi.org/10.1016/j .anifeedsci.2016.03.008.

Pacheco, D., G. Waghorn, and P. H. Janssen. 2014. Decreasing methane emissions from ruminants grazing forages: A fit with productive and financial realities? Anim. Prod. Sci. 54:1141-1154. https: //doi.org/10.1071/AN14437.

Packer, E. L., E. H. Clayton, and P. M. V. Cusack. 2011. Rumen fermentation and liveweight gain in beef cattle treated with monensin and grazing lush forage. Aust. J. Vet. Res. 89:338-345. https://doi .org/10.1111/j.1751-0813.2011.00802.x.

Pirondini, M., S. Colombini, M. Mele, L. Malagutti, L. Rapetti, G. Galassi, and G. M. Crovetto. 2015. Effect of dietary starch concentration and fish oil supplementation on milk yield and composition, diet digestibility, and methane emissions in lactating dairy cows. J. Dairy Sci. 98:357-372. https://doi.org/10.3168/jds.2014 -8092 .

Punia, B. S., J. Leibholz, and G. J. Faichney. 1987. The role of rumen protozoa in the utilization of paspalum (Paspalum dilatatum) hay by cattle. Br. J. Nutr. 57:395-406.

Tyrrell, H. F., and J. T. Reid. 1965. Prediction of the energy value of cow's milk. J. Dairy Sci. 48:1215-1223. https://doi.org/10.3168/ jds.S0022-0302(65)88430-2.

Van Kessel, J. A. S., and J. B. Russell. 1996. The effect of pH on ruminal methanogenesis. FEMS Microbiol. Ecol. 20:205-210. https:/ /doi.org/10.1016/0168-6496(96)00030-X.

Williams, S. R. O., T. Clarke, M. C. Hannah, L. C. Marett, P. J. Moate, M. J. Auldist, and W. J. Wales. 2013. Energy partitioning in herbage-fed dairy cows offered supplementary grain during an extended lactation. J. Dairy Sci. 96:484-494. https://doi.org/10 $.3168 /$ jds.2012-5787.

Williams, S. R. O., P. J. Moate, M. C. Hannah, B. E. Ribaux, W. J. Wales, and R. J. Eckard. 2011. Background matters with the $\mathrm{SF}_{6}$ tracer method for estimating enteric methane emissions from dairy cows. Anim. Feed Sci. Technol. 170:265-276. https://doi.org/10 .1016/j.anifeedsci.2011.08.013. 